\title{
A Predict Model to Evaluate the Level of HBV-DNA for the Patients With Chronic Hepatitis B Virus (CHB) in Clinic: a Cross-sectional Study
}

Jinli Zheng

Sichuan University West China Hospital

Juan Wan

Sichuan University West China Hospital

Chenhao Jiang

Sichuan University West China Hospital

Yang Huang

Sichuan University West China Hospital

Xingyu Pu

Sichuan University West China Hospital

Li Jiang ( $\nabla$ jianglihauxi@163.com )

Sichuan University West China Hospital

\section{Research}

Keywords: HBeAg-positive, HBeAg-negative, HBV DNA levels, Chronic Hepatitis B

Posted Date: January 23rd, 2021

DOI: https://doi.org/10.21203/rs.3.rs-151954/v1

License: (c) (1) This work is licensed under a Creative Commons Attribution 4.0 International License. Read Full License 


\section{Abstract}

Background: The previous studies showed the correlation between HBsAg and serum HBV DNA levels were weak or missing. And the relationship of HBeAg and HBV DNA levels was lack.

Objective: The study aims to investigate the correlation between HBeAg and HBV DNA levels, and to find an alternative tool to evaluate the HBV DNA levels for clinicians.

Methods: We enrolled 1020 patients in this cross-sectional study. We divided the patients into four groups as: HBeAg positivity and negativity groups, high and low HBV DNA levels groups. Further, as to the levels of HBV DNA, we performed subgroups' in HBeAg-positive and HBeAg-negative groups.

Results: The levels of ALT, ALB and HBeAg were the independent factors for the serum HBV DNA in CHB patients. The predict model for the patients with HBeAg-positive was: $M_{1}$ (high HBV DNA levels) $=1.412 \times$ ( 1 for HBeAg-positive $>16.15 \mathrm{~S} / \mathrm{CO}$ or 0 for others $)+0.004 \times(1$ for ALT $>42.5 \mathrm{IU} / \mathrm{L}$ or 0 for others $)-0.029$ $\times(1$ for ALB $>25.5 \mathrm{~g} / \mathrm{L}$ or 0 for others $)+0.779$, and the AUC was 0.606 . And the predict model of patients with HBeAg-negative was: $\mathrm{M}_{2}$ (low levels of HBV DNA $)=0.385-0.005 \times(1$ for ALT $>36.5 \mathrm{IU} / \mathrm{L}$ or 0 for others) $-0.006 \times$ ( 1 for TB $>11.15$ umol/L or 0 for others), and the AUC was 0.609 .

Conclusion: $\mathrm{HBeAg}$ was an independent risk factor for the patients with $\mathrm{HBeAg}(+)$, and when the level of HBeAg was higher than $16.15 \mathrm{~S} / \mathrm{CO}$, the patients should have a HBV-DNA test, if not, we should combine with the level of ALT to determine the decision. For the patients with $\mathrm{HBeAg}(-)$, we should evaluate the patients to have a HBV-DNA test by the levels of ALT and TB.

\section{Background}

Hepatitis B virus (HBV) infection is a serious public health problem worldwide. Previous studies have shown that approximately one-third of the world's population has HBV infection, and this infection is responsible for approximately 500,000 deaths annually, and over 350 million people facing been affected $[1,2]$. Further, HBV infection can cause acute or chronic hepatitis, cirrhosis, hepatic decompensation, and hepatocellular carcinoma [3].

Generally, the natural course of $\mathrm{CHB}$ includes several phases as following: I) I) immune tolerance phase (IT), with hepatitis B e antigen positivity (HBeAg (+)), high HBV-DNA levels, and normal levels of alanine aminotransferase (ALT). II) immune clearance phase (IC), with HBeAg (+), high HBV-DNA levels, normal or high ALT levels. III) low-replicative phase (LR), with HBeAg-negativity [HBeAg (-)], hepatitis B e antibody positivity (HbeAb [+]), undetectable levels of HBV DNA and normal ALT levels, iv) HBeAg-negative hepatitis (ENH), with HBeAg (-), HbeAb (+), high HBV DNA and ALT levels [4-7]. HBV DNA is a risk factor for liver cirrhosis, as Iloeje $\mathrm{UH}$, Yang $\mathrm{HI}$, et al. reported[8] that HBV DNA with the levels of $10^{4}-10^{5}$ copies/mL (2000-20000 IU/mL), $10^{5}-<10^{6}$ copies/mL (20000-200000 IU/mL) and $>10^{6}$ copies $/ \mathrm{mL}(200000 \mathrm{IU} / \mathrm{mL})$, the risks to develop into liver cirrhosis are 2.5, 5.6 and 6.5 folds, respectively. 
Testing the HBV DNA levers is a common method to evaluate the treatment decisions on patients and assess the response to antiviral therapy $[9,10]$. Previous studies have reported a correlation between the HBsAg and HBV DNA levels and have suggested $[6,11-14]$ serum HBsAg quantitation can be a marker to predict HBV DNA levels. However, similar studies have shown no correlations of HBsAg with HBV DNA [15-16]. Research trials have tested the quantification of serum HBsAg accurately to reflect the HBV DNA levers. Gupta E, Kumar A, et al.[11] reported that the best cut-off point of serum HBsAg quantification to predict the high HBV DNA levels is $3.36 \times 10^{3} \mathrm{IU} / \mathrm{ml}$, however, it is difficult to identify the quantification of serum HBeAg in clinic. On the other hand, the correlation with HBV DNA is weak or absent[15-16]. In fact, the HBV DNA levels are not exactly similar with the natural course of CHB. In clinic, the patients with HBeAg positivity (IT phase or IC phase) would have a high levels of serum HBV DNA, however, some patients would have a low HBV DNA levels. And the patients with HBeAg-negativity (LR phase and HBeAg-negative hepatitis phase) were believed to have low HBV DNA levels, however, a survey of HBeAgnegative patients showed that $47.5 \%$ of the patients in LR phase and $63.4 \%$ in the HBeAg-negative hepatitis phase with high HBV DNA levels (> $10^{4}$ copies/mL) [17]. Thus, HBV DNA levels would be high or undetected in both patients, $\mathrm{HBeAg}$-positive and HBeAg-negative. This phenomenon poses a challenge to clinicians, regarding when we should recommend a HBV DNA test for patients with CHB, because HBV DNA test was expensive, about 20 dollar in China. And it was insufficient evidence to convince the patient to have a HBV DAN test, especially for the developing country. Therefore, it needed an alternative tool to evaluate HBV DNA levels roughly and easily to provide an evidence to persuade the people to have a HBV DNA test.

$\mathrm{HBeAg}$ played a crucial role in HBV infection, meaning the high replication and high infectivity of $\mathrm{CHB}$ [18], and it would had a strong correlation with HBV DNA in previous studies, but there was few studies focus on searching the predict model to reflect the levels of HBV-DNA. This study aims to compare the difference between HBeAg-positive and HBeAg-negative patients, and to build an predict model to evaluate the HBV DNA levels.

\section{Materials And Methods}

\subsection{Patients}

We enrolled the patients at our center, the department of Liver Surgery and Liver Transplantation Center, West China Hospital of Sichuan University, from 2011 to 2013. The criteria wsa as following: 1) Age > 18 years, 2) having HBV DNA test in our center, and 3) positivity in HBsAg and HBeAg, or only positive with HBsAg on serum HBV test. Patients were excluded when they met one of the criteria: 1) co-infection with other hepatitis viruses, such as hepatitis $C, A$, and $D ; 2$ ) acute hepatitis, especially acute liver failure; and 3) had received antivirus treatment at other centers.

According to previous studies $[7,8,11]$, high HBV DNA level was defined as $>2000 \mathrm{IU} / \mathrm{mL}\left(2 \times 10^{3}\right.$ copies $/ \mathrm{mL}$ ). 


\subsection{Methods}

We divided the patients into four groups as: HBeAg positivity group and HBeAg negativity group, high HBV DNA levels group and low HBV DNA levels group. Further, we performed subgroup analyses for the HBeAg-positive and HBeAg-negative groups.

\subsection{Statistical analysis}

All the data were analyzed using SPSS 22.0 data statistical software (SPSS Inc., Chicago, IL, USA). Continuous variables are expressed as mean \pm standard deviation ( $\overline{\mathrm{x}} \pm \mathrm{sd})$ values. Between-group comparisons of the continuous variables were made using T-test or W-test, and the optimal predictive cutoff value was determined by Receiver Operating Characteristics (ROC) curves. Using logistic regression multivariate analysis to identify the independent risk and building a predict model. The categorical variables were analyzed using chi-square test $\left(\chi^{2}\right)$. For all the analyses, $P$ value $<0.05$ was considered statistically significant.

\section{Results}

\subsection{Characteristic of $\mathrm{HBeAg}(+)$ and $\mathrm{HBeAg}(-)$ patients}

We enrolled 1020 patients in this study from January 2011 to December 2013, including 881 males and 139 females; 252 patients were $\mathrm{HBeAg}$-positive (HBeAg (+)) and 768 were $\mathrm{HBeAg}$-negative (HBeAg (-)); 535 had high HBV DNA levels and 585 had low HBV DNA levels. The characteristics of the patients was shown in table 1 . The values of age, the platelet count (PLT), aspartate aminotransferase (AST), and high HBV DNA levels are significant between the patients of $\mathrm{HBeAg}(+)$ and $\mathrm{HBeAg}(-)$. The $\mathrm{HBeAg}(+)$ patients was younger, lower PLT levels, and higher AST levels than the HBeAg(-) patients. In contrast, the white blood cell (WBC) count and the levels of hemoglobin (HGB), total bilirubin (TB), alanine aminotransferase (ALT), albumin (ALB), and prothrombin time wasn't significant. From Fig. 1-A, evaluating the CHB patients with a high HBV DNA levels by $\mathrm{HBeAg}(+)$ might be reliable, for the area of under the curve (AUC) was 0.622 .

\subsection{Characteristic in different HBV DNA levels}

Table 1 showed the feature of high HBV DNA levels and low HBV DNA levels. The difference of PLT, AST, $A L T$, and ALB were significant between the groups, and the ROC of predicting the patients with a high HBV-DNA level was shown in Fig. 1-B. The AUC of AST, ALT, ALB, and PLT was 0.635, 0.642, 0.432, and 0.473 , respectively, and the optimal cutoff points were $46.5 \mathrm{IU} / \mathrm{L}, 42.5 \mathrm{IU} / \mathrm{L}, 25.5 \mathrm{~g} / \mathrm{L}$, and $74.5 \times 10^{9} / \mathrm{L}$, respectively. The levels of AST and ALT were higher in high HBV DNA group, and the levels of PLT and ALB were lower. Furthermore, the logistic regression multivariate analyses showed the PLT and AST weren't significant.

\subsection{The different HBV DNA levels in HBeAg (+) patients}


The difference of the $\mathrm{HBeAg}(+)$ patients with high and low HBV DNA levels was shown in table 2. The sex, age, PLT, WBC, TB, AST, and ALT were not significant. The variables of HGB, ALT, and HBeAg were significant, and the AUC was $0.394,0.379$, and 0.787 , respectively, with the optimal cut-off points being $170.5 \mathrm{~g} / \mathrm{L}, 25.0 \mathrm{~g} / \mathrm{L}$, and $16.15 \mathrm{~S} / \mathrm{CO}$, respectively, (Fig. 1-C).

\subsection{The different HBV DNA levels in HBeAg (-) patients}

Table 2 summarized the HBV DNA levels characteristics of $\mathrm{HBeAg}(-)$ patients. The variables of TB, AST, and ALT were significantly difference between the groups. The AUC of these variables was $0.511,0.628$, and 0.655 , respectively (Fig. 1-D), and the cutoff values were $11.15 \mathrm{umol} / \mathrm{L}, 36.5 \mathrm{U} / \mathrm{L}$, and $42.5 \mathrm{U} / \mathrm{L}$, respectively.

\subsection{The logistic regression multivariate analysis in $\mathrm{CHB}$ patients and $\mathrm{HBeAg}(-)$ patients}

Table 3 showed the logistic regression multivariate analysis of the $1020 \mathrm{CHB}$ patients and the paitents with $\mathrm{HBeAg}(-)$. Through the logistic regression multivariate analysis and univariate analysis, the independent risk factors of CHB patients with high HBV-DNA level were ALT, ALB and HBeAg (table 3). And we could draw the predict model of the CHB patients with a high HBV DNA level as:

$\mathrm{M}_{1}$ (high HBV DNA levels $)=1.412 \times(1$ for HBeAg-positive $>16.15 \mathrm{~S} / \mathrm{CO}$ or 0 for others $)+0.004 \times(1$ for ALT $>42.5 \mathrm{IU} / \mathrm{L}$ or 0 for others $)-0.029 \times(1$ for $A L B>25.5 \mathrm{~g} / \mathrm{L}$ or 0 for others $)+0.779$

The ROC of the predictive model $M_{1}$ was shown in Fig. 2-A. The AUC was 0.606 , and the cutoff value was 0.752 .

On the other hand, for the logistic regression multivariate analysis, only TB and ALT were significant for the patients with $\mathrm{HBeAg}(-)$ (table 3). Combining with the univatiate analysis (table 2), the level of TB and ALT were the independent risk factors for the $\mathrm{HBeAg}(-)$ patients with high HBV-DNA level. Following the result, we drew the predict model of $\mathrm{HBeAg}(-)$ patients with a low HBV DNA levels as:

$M_{2}$ (low levels of HBV DNA $)=0.385-0.005 \times(1$ for ALT $>36.5 \mathrm{IU} / \mathrm{L}$ or 0 for others $)-0.006 \times(1$ for TB $>$ $11.15 \mathrm{umol} / \mathrm{L}$ or 0 for others)

The ROC of the predictive model $M_{2}$ was shown in Fig. 2-B. The AUC was 0.609 , and the cutoff value was 0.3765 .

\section{Discussion}

HBV DNA was a marker of antivirus treatment response and high infectivity in CHB patients. The different phases of the natural course of CHB had their own specific characteristics, and we couldn't evaluate the levels of serum HBV DNA as per the course of CHB [17]. Previous studies have shown a weak or absent correlation between HBsAg and HBV DNA levels[11-16]. To our knowledge, few studies have assessed the correlation between HBeAg and serum HBV DNA. A survey carried by Ping Chen, Qinfen Xie, et al. [30] 


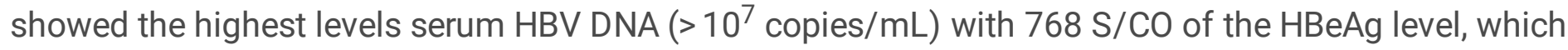
could just indicate the relationship of HBV DNA levels in IT phage. In this study, we analyzed the whole course of $\mathrm{CHB}$ in clinic. The results were shown in table 1 . The $\mathrm{HBeAg}(+)$ patients were younger than the HBeAg(-) patients $(p<0.001$, table 1$)$, however, the age in the serum HBV DNA levels group were not significant difference $(p=0.394$, table 1$)$. The patients in different stages of life acquisition of the virus would show differences in the behavior of HBeAg. The previous study[19] showed that when a patient is infected at birth or at 1-2 years of age, they experienced a prolonged IC phase. In contrast, infected after early children, the patients generally do not experience the IT phase, they will enter the LR phage quickly, and the levels of serum HBV DNA didn't mean low. So the age wasn't a reasonable factor to predict the serum HBV DNA of patients with HBeAg-positive .

The PLT count was different between the $\mathrm{HBeAg}(+)$ and $\mathrm{HBeAg}(-)$ patients as well as those with high and low levels of serum HBV DNA ( $p_{1}=0.001$ and $p_{2}=0.011$, table 1$)$. However, in subgroups' analyses showed a non-significant difference $\left(p_{1}=0.739\right.$ and $p_{2}=0.086$, table 2$)$. An animal model has suggested a link between the PLT count and immune control of HBV infection [20,21]. We carried this study to build the model by analyzing the whole natural course of the $\mathrm{CHB}$, and we divided the patients into two groups: 1) the PLT count in $\mathrm{HBeAg}(+)$ and $\mathrm{HBeAg}(-)$ group; 2$)$ the PLT count in high HBV DNA levels and low HBV DNA levels group. We found that the PLT was significant difference in $\mathrm{HBeAg}(+)$ and $\mathrm{HBeAg}(-)$ groups ( 121.6 vs $140.81, p=0.001$, table 1 ), and the high HBV DNA levels and the low serum HBV DNA groups ( 129.84 vs $142.87, p=0.011$, table 1 ), but the levels of PLT count was in normal range, which couldn't convey a useful information to identify the levels of serum HBV DNA. Further, the multivariate analysis also eliminated the PLT count to predict the serum HBV DNA. Therefore, the correlation between PLT and HBV DNA level needed further research.

The level of ALT was very important in CHB patients because it was a marker of liver function damage. To clarify the natural course of CHB was based on biochemical, serological, and virological characteristics, including serum ALT levels, HBeAg serostatus, and HBV DNA levels [4-7]. Some studies have pointed out that although the level of AST was normal, the levels of serum HBV DNA was needed to test $[22,23]$. On the other hand, the high ALT levels might be associated with HBV replication throughout the course of chronic HBV infection that did harm to the liver [24]. Combining with the multivariate analysis, the levels of ALT was an independent factor to predict the levels of serum HBV DNA, but the odds ratio (OR) was 1.004 and 1.005 in natural course of $\mathrm{HBV}$ and the patient with $\mathrm{HBeAg}(-)$, respectively (table 3). The correlation was weak, especially for the patient in $\mathrm{HBeAg}(+)$ group, because the $\mathrm{HBeAg}(+)$ has a strong correlation of HBV DNA ( OR $=4.104$, table 3 ). However, the levels of ALT as a factor to predict the levels of HBV DNA in $\mathrm{HBeAg}(-)$ group was credible, for the AUC was 0.655 (Fig. 1-D) and there was no strong factor to predict the high levels of HBV-DNA in HBeAg(-) patients. There were also some questions that several studies have reported that the AST levels may vary with body mass index, abnormal lipid and carbohydrate metabolism, and the time of the day $[25,26]$. We needed to pay attention to these factors while evaluating the HBV DNA levels of $\mathrm{HBeAg}(-)$ patients. 
Previous studies have reported a weak or absent correlation between HBsAg levels and HBV DNA levels [11-16]. The serum HBsAg levels were higher in the $\mathrm{HBeAg}(+)$ patients than in the $\mathrm{HBeAg}(-)$ patients [6, 24], but as the previous studies reported that the level of HBsAg higher than $3000 \mathrm{lU} / \mathrm{ml}$ was a reference for predicting the high HBV DNA level, which wasn't convenient for clinicians. HBeAg could be as a sign of the high replication and infectivity of $\mathrm{CHB}$ [17]. In our research, we found that according to $\mathrm{HBeAg}$ levlels to predict the high HBV DNA levels was reliable, because the AUC of ROC was 0.622 (Fig. 1-A), and when the HBeAg levels higher than $16.15 \mathrm{~S} / \mathrm{CO}$, it was 4 times to have a high HBV DNA levels than those not. Following the predict model $\mathrm{M}_{1}$ (high HBV DNA levels $)=1.412 \times(1$ for HBeAg-positive $>16.15 \mathrm{~S} / \mathrm{CO}$ or 0 for others $)+0.004 \times(1$ for ALT > $42.5 \mathrm{IU} / \mathrm{L}$ or 0 for others $)-0.029 \times(1$ for ALB $>25.5 \mathrm{~g} / \mathrm{L}$ or 0 for others) +0.779 , and the cut-off value was 0.752 . We could explain that the $\mathrm{HBeAg}(+)$ patients was likely to have a high level of serum HBV DNA, when the levels of HBeAg wad higher than $16.15 \mathrm{~S} / \mathrm{CO}$. But if the level of HBeAg was lower than $16.15 \mathrm{~S} / \mathrm{CO}$, we should combine the level of ALB and ALT to evaluate the high HBV DNA levels (table 2),especially for the level of ALT. Because when the level of ALT was higher that $42.5 \mathrm{IU} / L$, the value of $M_{1}$ would be higher than 0.752 , meaning the patient would have a high level of HBV-DNA ( $>2 \times 10^{3}$ copies $/ \mathrm{mL}$ ), and the patients needed a HBV-DNA test.

$\mathrm{HBeAg}(-)$ was usually correlated with lower intrahepatic cccDNA levels [27-29]. Therefore, the serum HBV DNA levels were different between $\mathrm{HBeAg}(+)$ and $\mathrm{HBeAg}(-)$ patients. However, Lai CL, Ratziu V, et al. [19] reported that $\mathrm{HBeAg}(-)$ patients didn't mean the levels of serum HBV DNA was low. With the analysis of logistic regression multivariate analysis, the independent risk factors to predict the serum HBV DNA in $\mathrm{HBeAg}(-)$ patients were the levels of TB and ALT, and the cut-off values were $11.15 \mathrm{umol} / \mathrm{L}$ and $36.5 \mathrm{IU} / \mathrm{L}$, respectively (table 2). Following the predict model $M_{2}$ (low levels of HBV DNA $)=0.385-0.005 \times(1 \mathrm{for}$ ALT > 36.5 IU/L or 0 for others $)-0.006 \times$ ( 1 for TB $>11.15 \mathrm{umol} / \mathrm{L}$ or 0 for others), and the cutoff value was 0.3765 . We found that when the levels of TB and ALT both were higher than $11.15 \mathrm{umol} / \mathrm{L}$ and $36.5 \mathrm{IU} / \mathrm{L}$, together, the patients would have a high level of HBV-DNA and should have a HBV-DNA test. Though the levels of TB and ALT were in the normal range, which was contradict with phages of lowreplicate with $\mathrm{HBeAg}(-)$ hepatitis [5-8]. On the other hand, the HBV infection was throughout the all phages of natural course, we shouldn't ignore the levels of HBV-DNA in HBeAg(-) patients.

Actually, the HBV-DNA test was the convenient, direct and accurate method to reflect the republication of $\mathrm{HBV}$, but the cost was high and the medical compliance was poor in the developing country. On the other hand, combining the findings of our research, we might reduce the expense and persuade the patients to have the HBV-DNA test. Inevitably, the study also had the following limitations: i) cross-sectional retrospective studies needed a long-term follow-up to identify the parameters that reflect the response of patients who had received the antivirus treatment, especially those who had high levels of serum HBV DNA and were HBeAg-positive. In the current study, we did not perform follow-up to search the effect of antiviral treatment ii) We did not divide the patients into different phases as per the natural course of $\mathrm{CHB}$. We studied the entire cohort of CHB patients, and this might not reflect the real levels of serum HBV DNA in HBeAg-negative patients iii) The levels of serum HBV DNA might be different between HBVgenotype $A$ and $D$, and we did not evaluate the HBV-genotype in the CHB patients. 


\section{Conclusion}

$\mathrm{HBeAg}$ was an independent risk factor for the patients with $\mathrm{HBeAg}(+)$, and when the level of $\mathrm{HBeAg}$ was higher than $16.15 \mathrm{~S} / \mathrm{CO}$, the patients should have a HBV-DNA test, if not, we should combine with the level of ALT to determine the decision. For the patients with $\mathrm{HBeAg}(-)$, we should evaluate the patients to have a HBV-DNA test by the levels of ALT and TB.

\section{Abbreviations}

HBsAg: Hepatitis B surface antigen, HBeAg: Hepatitis B 'e' antigen, HBeAb: Hepatitis B 'e' antibody, CHB: Chronic Hepatitis B, HBV: Hepatitis B virus; HGB: Hemoglobin, PLT: Platelet, WBC : White blood cell, TB: Total bilirubin, AST: Aspartate aminotransferase, ALT: Alanine aminotransferase, ALB: Albumin, PT: Prothrombin time.

\section{Declarations}

\section{Ethics approval and consent to participate}

This study was approved by the West China Hospital Ethics Committee, and in accordance with the ethical guidelines of the Declaration of Helsinki.

\section{Consent for publication}

Not applicable.

\section{Availability of data and materials}

The data sets used during the current study are available from the corresponding author on reasonable request.

\section{Competing interests}

The authors declare that they have no competing interests.

\section{Funding}

This study was supported by grants from the National Sciences (2012ZX10002-016) and Technology Major Project of China(2012ZX10002-017), provided by JY Yang, providing to collect the data. And the National Natural Science Foundation of China (81400636), Sichuan Province Key Research and Development Project (2019YFS0203), and the Key Project of Clinical Research Incubation in West China Hospital of Sichuan University (2020HXFH028), provided by L Jiang, to supported the study designing, data analysis and interpretation, writting the manuscript and scientific language editing, respectively. 
Author Contributions:Study conception and design: LJ; Acquisition of data: JLZ, WJ and CHJ; Collected and copied imaging picture: YH and JLZ; Analysis and interpretation of data: LJ and JLZ; Drafting of manuscript: JLZ and WJ; Critical revision: LJ; XYP and JLZ contributed in statistical analysis. All authors have read and approved the manuscript.

\section{Acknowledgments}

Thanks for the www. enago. cn provided scientific language editing service. And the funding supported by JY Yang and LJ.

\section{References}

1. Ganem D, Prince AM. Hepatitis B virus infection - natural history and clinical consequences. N Engl J Med 2004;350:1118-29.

2. Ocana S, Casas ML, Buhigas I, Lledo JL. Diagnostic strategy for occult hepatitis B virus infection. World J Gastroenterol. 2011; 17(12):1553-7.

3. Kao JH, Chen DS. Global control of hepatitis B virus infection. Lancet Infect Dis 2002;2:395-403.

4. Shi YH and Shi CH. Molecular characteristics and stages of chronic hepatitis B virus infection. World J Gastroenterol 2009;15(25): 3099-105.

5. Kim YJ, Cho HC, Choi MS, Lee JH, Koh KC, Yoo BC, et al. The change of the quantitative HBsAg level during the natural course of chronic hepatitis B. Liver International 2011; 31(6):817-23.

6. Jaroszewicz J, Calle Serrano B, Wursthorn K, Deterding K, Schlue J, Raupach R, et al. Hepatitis B surface antigen (HBsAg) levels in the natural history of hepatitis B virus (HBV)-infection: A European perspective. Journal of Hepatology 2010;52(4):514-522.

7. Liaw, YF, Kao JH, Piratvisuth T, Chan HL, Chien RN, Liu CJ, et al. Asian-Pacific consensus statement on the management of chronic hepatitis B: a 2012 update. Hepatol Int. 2012; 6(3): 531 - 561.

8. Iloeje UH, Yang HI, Su J, Jen CL, You SL, Chen CJ. Predicting cirrhosis risk based on the level of circulating hepatitis B viral load. Gastroenterology 2006;130(3):678-86.

9. Gish RG, Locarnini SA. Chronic hepatitis B: Current testing strategies. Clin Gastroenterol Hepatol 2006;4(6):666 - 76.

10. Andersson KL, Chung RT. Monitoring During and After Antiviral Therapy for Hepatitis B. Hepatology 2009;49(5 suppl):S166 - 73.

11. Gupta E, Kumar A, Choudhary A, Kumar M, Sarin SK. Serum hepatitis B surface antigen levels correlate with high serum HBV DNA levels in patients with chronic hepatitis B: a cross-sectional study. Indian J Med Microbiol 2012;30(2): 150-54.

12. Nguyen T, Thompson AJ, Bowden S, Croagh C, Bell S, Desmond PV, et al. Hepatitis B surface antigen levels during the natural history of chronic hepatitis B: A perspective on Asia. J Hepatol 2010;52(4):508-13. 
13. Vigano M, Lampertico P. Clinical implications of HBsAg quantification in patients with chronic hepatitis B. Saudi J Gastroenterol 2012;18(2):81-6.

14. Alghamdi A, Aref N, El-Hazmi M, Al-Hamoudi W, Alswat K, Helmy A, et al. Correlation between Hepatitis B surface antigen titers and HBV DNA levels. Saudi J Gastroenterol 2013;19(6):252-7.

15. Brunetto MR, Oliveri F, Colombatto P, Moriconi F, Ciccorossi P, Coco B, et al. Hepatitis B surface antigen serum levels help to distinguish active from inactive hepatitis $B$ virus genotype $D$ carriers. Gastroenterology 2010;139(2):483-90.

16. Kim YJ, Cho HC, Choi MS, Lee JH, Koh KC, Yoo BC, et al. The change of the quantitative HBsAg level during the natural course of chronic hepatitis B. Liver Int 2011;31(6):817- 23.

17. Lin CL, Liao LY, Liu CJ, Yu MW, Chen PJ, Lai MY, et al.Hepatitis B viral factors in HBeAg-negative carriers with persistently normal serum alanine aminotransferase levels. Hepatology. 2007;45(5):1193-8.

18. Dwivedi M, Misra SP, Misra V, Pandey A, Pant S, Singh R, et al. Seroprevalence of hepatitis B infection during pregnancy and risk of perinatal transmission. Indian J Gastroenterol 2011, 30(2): 66-71.

19. Lai CL, Ratziu V, Yuen MF, Poynard T. Viral hepatitis B.Lancet. 2003;362(9401):2089-94.

20. Iannacone M, Sitia G, Isogawa M, Marchese P, Castro MG, Lowenstein PR, et al. Platelets mediate cytotoxic T lymphocyte-induced liver damage. Nat Med 2005;11(11):1167-1169.

21. Iannacone M, Sitia G, Guidotti LG. On the role of platelets in the pathogenesis of viral hepatitis. J Hepatol 2009;51(3):599-600.

22. Iloeje UH, Yang HI, Su J, Jen CL, You SL, Chen CJ, et al. Predicting cirrhosis risk based on the level of circulating hepatitis B viral load. Gastroenterology. 2006;130(3):678-86.

23. Sarin SK, Kumar M. Should chronic HBV infected patients with normal ALT treated: debate. Hepatol Int 2008; 2(2):179-184.

24. Zeng DW, Liu YR, Dong J, Zhu YY, Li YB,Chen J, et al. Serum HBsAg and HBeAg levels are associated with liver pathological stages in the immune clearance phase of hepatitis $B$ virus chronic infection. MOLECULAR MEDICINE REPORTS 2015; 11(5): 3465-72.

25. Piton A, Poynard T, Imbert-Bismut F, Khalil L, Delattre J, Pelissier E, et al. Factors associated with serum alanine transaminase activity in healthy patients: consequences for the definition of normal values, for selection of blood donors, and for patients with chronic hepatitis C. MULTIVIRC Group. Hepatology. 1998;27(5):1213-9.

26. Kim HC, Nam CM, Jee SH, Han KH, Oh DK, Suh I. Normal serum aminotransferase concentration and risk of mortality from liver diseases: prospective cohort study. BMJ. 2004;328(7446):983-8.

27. Werle-Lapostolle B, Bowden S, Locarnini S, Wursthorn K, Petersen J, Lau G, et al. Persistence of cccDNA during the natural history of chronic hepatitis $B$ and decline during adefovir dipivoxil therapy. Gastroenterology 2004;126(7):1750-58.

28. Wursthorn K, Lutgehetmann M, Dandri M, Volz T, Buggisch P, Zollner B, et al. Peginterferon alpha-2b plus adefovir induce strong cccDNA decline and HBsAg reduction in patients with chronic hepatitis B. 
Hepatology. 2006;44(3):675-684.

29. Chan HL, Wong VW, Tse AM, Tse CH, Chim AM, Chan HY, et al. Serum hepatitis B surface antigen quantitation can reflect hepatitis $B$ virus in the liver and predict treatment response. Clin Gastroenterol Hepatol. 2007;5(12):1462-1468.

30. Chen P, Xie Q, Lu X, Yu C, Xu K, Ruan B, et al. Serum HBeAg and HBV DNA levels are not always proportional and only high levels of HBeAg most likely correlate with high levels of HBV DNA A community-based study. Medicine. 2017, 96(33): e7766.

\section{Tables}

Tables not available with this version.

\section{Figures}

\section{Image not available with this version}

\section{Figure 1}

$A$ : The ROC of judging the HBV DNA levels by HBeAg-positive of the patients with $\mathrm{CHB}$, and the AUC is 0.622. B: The ROC of significant factors in different levels of HBV DNA. These factors are AST, ALT, ALB and PLT, and the AUC $0.635,0.642,0.432$ and 0.473 , respectively. The best cut-off value is $46.5 \mathrm{IU} / \mathrm{L}, 42.5$ IU/L, $25.5 \mathrm{IU} / \mathrm{L}$ and $74.5 \times 10^{\wedge} 9$ /L respectively. C: The ROC of HBeAg, ALB and HGB in CHB with HBeAgpositive, and the ACU of HBeAg, ALB and HB are 0.787, 0.379 and 0.394 respectively. The best cut-off value of HBeAg is $16.15 \mathrm{~S} / \mathrm{CO}$. D: The ROC of TB, AST and ALT in the patients with HBeAg-negative, the AUC and cut-off value are $0.511,0.628,0.655$ and $11.15 \mathrm{umol} / \mathrm{L}, 42.5 \mathrm{IU} / \mathrm{L}, 36.5 \mathrm{IU} / \mathrm{L}$, respectively. 


\section{Image not available with this version}

\section{Figure 2}

A: Different HBV DNA levels in CHB. The ROC of predict model M1 (high HBV DNA level), the ACU and best cut-off value are 0.606 and 0.752 , respectively. B: The HBV DNA levels in HBeAg-negative. The ROC of predict model M2 (low HBV DNA level in $\mathrm{HBeAg}(-)$ ), the AUC and cut-off value are 0.609 and 0.376 , respectively. 